\title{
PENGARUH PENERAPAN MODEL PEMBELAJARAN AUDITORY INTELLECTUALLY REPETITION (AIR) TERHADAP KEMAMPUAN KOMUNIKASI MATEMATIKA SISWA DI KELAS VIII SMP NEGERI 1 PASIR PENYU
}

\author{
Helma Mustika ${ }^{1}$, Nuri Kinanti ${ }^{2}$ \\ ${ }^{1}$ Dosen Program Studi Pendidikan Matematika STKIP Insan Madani Airmolek \\ ${ }^{2}$ Mahasiswa Program Studi Pendidikan Matematika STKIP Insan Madani Airmolek \\ 1'helmamustika@ymail.com, ${ }^{2}$ kikinkinanti61@yahoo.com
}

\begin{abstract}
This research is based on the students' mathematical communication ability at SMP Negeri 1 Pasir Penyu which is still low. To overcome the problem is applied learning model Auditory Intellectually Repetition (AIR). This study aims to determine the ability of students' mathematical communication using the learning model of Auditory Intellectually Repetition (AIR). This research type is quasi experiment research. The research design used was randomized subjects posttest only control group design. The sampling technique used is cluster random sampling. After the sample was taken randomly, the students selected VIII.6 class as experimental class and students of class VIII.5 as the control class. The instrument in this research is a test of students' mathematical communication skill. The data analysis technique used Independent Samples T-Test (t-test) test. Based on hypothesis test results obtained that tcount = $5,065>$ ttable $=2.002$ with $(d f=60)$ and a real level of $5 \%$. Reject $H_{0}$ if thitung value is ttable. So it can be concluded that the mathematical communication skills of students using the learning model of Auditory Intellectually Repetition (AIR) is better than the students' mathematical communication skills using conventional learning model.
\end{abstract}

Keywords: Auditory Intellectually Repetition (AIR), mathematical communication.

\begin{abstract}
Abstrak. Penelitian ini dilatar belakangi oleh kemampuan komunikasi matematika siswa di SMP Negeri 1 Pasir Penyu yang masih rendah. Untuk mengatasi permasalahan tersebut diterapkanlah model pembelajaran Auditory Intellectually Repetition (AIR). Penelitian ini bertujuan untuk mengetahui kemampuan komunikasi matematika siswa dengan menggunakan model pembelajaran Auditory Intellectually Repetition (AIR). Jenis penelitian ini adalah penelitian quasi eksperimen. Rancangan penelitian yang digunakan adalah randomized subjects posttest only control group design. Teknik pengambilan sampel yang digunakan adalah cluster random sampling. Setelah sampel diambil secara acak, terpilih siswa kelas VIII.6 sebagai kelas eksperimen dan siswa kelas VIII.5 sebagai kelas kontrol. Instrumen dalam penelitian ini berupa tes kemampuan komunikasi matematika siswa. Teknik analisis data menggunakan uji Independent Samples T-Test (uji-t ). Berdasarkan hasil uji hipotesis diperoleh bahwa nilai $\mathrm{t}_{\text {hitung }}=5.065>\mathrm{t}_{\text {tabel }}=2.002$ dengan $(\mathrm{df}=60)$ dan taraf nyata $5 \%$. Tolak $\mathrm{H}_{0}$ jika nilai $\mathrm{t}_{\text {hitung }}>\mathrm{t}_{\text {tabel }}$. Jadi dapat disimpulkan bahwa kemampuan komunikasi matematika siswa dengan menggunakan model pembelajaran Auditory Intellectually Repetition (AIR) lebih baik dari pada kemampuan komunikasi matematika siswa dengan menggunakan model pembelajaran konvensional.
\end{abstract}

Kata Kunci: Auditory Intellectually Repetition (AIR), komunikasi matematika.

\section{PENDAHULUAN}

Matematika merupakan ilmu universal yang mendasari perkembangan ilmu pengetahuan, teknologi modern dan daya pikir manusia. Hal ini dijelaskan oleh Ismail, dkk yaitu Matematika adalah ilmu yang membahas angka-angka dan perhitungannya, membahas masalah-masalah numerik, mengenai kuantitas dan besaran, mempelajari hubungan pola, bentuk dan struktur, sarana berfikir, kumpulan sistem, struktur dan 
alat. Pada hakikatnya, matematika tidak terlepas dari kehidupan sehari-hari. Semua masalah kehidupan yang membutuhkan pemecahan masalah secara cermat dan teliti mau tidak mau harus berpaling kepada matematika. Oleh karena itu, matematika merupakan ilmu dasar yang diperlukan untuk menunjang keberhasilan dalam menempuh jenjang pendidikan, mulai dari jenjang pendidikan dasar, menengah sampai jenjang pendidikan tinggi yang harus dikuasi oleh setiap siswa.

Berdasarkan tujuan pembelajaran matematika di atas, salah satu tujuan penting dalam pembelajaran matematika adalah komunikasi matematika. Karena matematika merupakan alat komunikasi yang sangat kuat, teliti dan tidak membingungkan. Sehingga dengan mengkomunikasikan gagasan dengan matematika lebih praktis, sistematis dan efisien. Berdasarkan hasil observasi yang peneliti lakukan terhadap proses pembelajaran matematika di kelas VIII SMP Negeri 1 Pasir Penyu, menemukan permasalahan yaitu: Siswa kurang bisa membaca simbol, bahkan tidak mampu memodelkan dengan cara matematika serta banyak siswa yang malas dan sulit mengerjakan suatu permasalahan jika penyajiannya berbeda, dan ketika diminta menjelaskan jawaban kepada teman-teman siswa cendrung membaca apa yang ditulisnya.

Hal ini ditunjukan dengan hasil Tes Kemampuan komunikasi matematika siswa rendah. Hal ini dapat dilihat dari nilai Tes Kemampuan komunikasi Matematika siswa kelas VIII dengan Kriteria Ketuntasan Minimun (KKM) yang ditetapkan SMP N 1 Pasir Penyu untuk pembelajaran matematika yaitu 76. Hasil Tes Kemampuan Komunikasi matematika siswa kelas VIII SMP N 1 Pasir Penyu T.A 2016/2017 dapat dilihat pada Tabel 1 berikut.

Tabel 1. Distribusi Nilai Tes Kemampuan Komunikasi Matematika Siswa Kelas VIII SMP N 1 Pasir Penyu T.A 2016/2017

\begin{tabular}{ccccc}
\hline \multirow{2}{*}{ No } & \multirow{2}{*}{ Kelas } & Jumlah & \multicolumn{2}{c}{ Nilai } \\
\cline { 4 - 5 } & & siswa & Nilai $<\mathbf{7 6}$ & Nilai $>\mathbf{7 6}$ \\
\hline 1 & VIII 1 & 32 & 0 & 32 \\
\hline 2 & VIII 2 & 31 & 5 & 26 \\
\hline 3 & VIII 3 & 31 & 15 & 16 \\
\hline 4 & VIII 4 & 31 & 30 & 1 \\
\hline 5 & VIII 5 & 27 & 14 & 13 \\
\hline 6 & VIII 6 & 29 & 21 & 8 \\
\hline 7 & VIII 7 & 26 & 26 & 0 \\
\hline \multicolumn{2}{c}{ Jumlah } & $\mathbf{2 0 7}$ & $\mathbf{1 1 1}$ & $\mathbf{9 6}$ \\
\hline
\end{tabular}

Berdasarkan tabel 1 dapat dilihat bahwa, sebagian besar siswa lebih banyak memiliki nilai tes kemampuan komunikasi matematika siswa yang kurang dari KKM. Salah satu model pembelajaran yang dapat melatih kemampuan komunikasi matematika siswa adalah dengan model pembelajaran Auditory, Intellectually, Repetiton (AIR). Model pembelajaran Auditory, Intellectually, Repetition (AIR) adalah model pembelajaran yang menganggap bahwa suatu pembelajaran akan efektif jika memperhatikan tiga hal yaitu: Auditory (mendengar), Intellectually (berpikir), dan Repetition (pengulangan). 
Model pembelajaran memberikan kerangka dan arah bagi guru untuk mengajar, sehingga tercapai tujuan yang hendak dicapai. Model pembelajaran AIR merupakan singkatan dari Auditory, Intellectually, Repetiton. Auditory bermakna bahwa belajar haruslah melalui mendengarkan, menyimak, berbicara, presentasi, argumentasi, mengemukakan pendapat, dan menanggapi. Intellectualy menunjukkan apa yang dilakukan pembelajaran dalam pemikiran suatu pengalaman dan menciptakan hubungan makna, rencana dan nilai dari pengalaman tersebut. Repetition merupakan pengulangan, dengan tujuan memperdalam dan memperluas pemahaman siswa yang perlu dilatih melalui pengerjaan soal, pemberian tugas dan kuis. Dalam teori Thorndike penerapan dalam model pembelajaranan adalah pengulangan terhadap penyampaian materi dan latihan, dapat membantu siswa mengingat materi terkait lebih lama.

Langkah-langkah Model Pembelajaran Auditory Intellectually Repetition (AIR) yaitu: 1) Siswa dibagi menjadi beberapa kelompok, masing-masing kelompok 4-5 anggota; 2) Siswa mendengarkan dan memerhatikan penjelasan dari guru; 3) Setiap kelompok mendiskusikan tentang materi yang mereka pelajari dan menuliskan hasil diskusi tersebut dan selanjutnya untuk dipresentasikan di depan kelas (auditory); 4) Saat diskusi berlangsung, siswa mendapat soal atau permasalahan yang berkaitan dengan materi; 5) Masing-masing kelompok memikirkan cara menerapkan hasil diskusi serta dapat meningkatkan kemampuan mereka untuk meyelesaikan masalah (intellectual); dan 6) Setelah selesai berdiskusi, siswa mendapat pengulangan materi dengan cara mendapatkan tugas atau kuis untuk tiap individu (repetition).

\section{METODE}

Dilihat dari tujuan penelitian, maka jenis penelitian ini adalah penelitian eksperimen (experimental research). Desain penelitian yang digunakan adalah Quasi Experimental Design. Adapun rancangan penelitian yaitu Randomized Subjects Posstest Only Control Group Design dapat digambarkan pada Tabel 2 berikut.

Tabel 2. Bentuk Randomized Subjects Posttest Only Control Group Design

\begin{tabular}{cccc}
\hline Group & $\begin{array}{c}\text { Variabel } \\
\text { Terikat }\end{array}$ & Postest \\
\hline $\mathrm{R}$ & Eksperimen & $\mathrm{X}$ & $Y_{2}$ \\
\hline $\mathrm{R}$ & Kontrol & - & $Y_{2}$ \\
\hline
\end{tabular}

Populasi dalam penelitian ini adalah siswa kelas VIII yang berjumlah 216 siswa. Akan tetapi, 64 siswa merupakan siswa kelas unggul yaitu VIII 1 dan VIII 2, maka yang menjadi populasi dalam penelitian ini yaitu VIII 3, VIII 4, VIII 5, VIII 6 dan VIII 7 yang berjumlah 152 siswa. Untuk menentukan sampel yang representatif penulis menggunakan metode pengambilan sampel secara cluster (kelompok) random sampling. Metode cluster yaitu metode pemilihan sampel yang diaplikasikan pada populasi yang terdiri dari kelompok- kelompok (cluster) tertentu. Teknik cluster random sampling adalah pengambilan sampel setiap kelompok dilakukan secara random. Dari pengundian, kelas yang terambil pertama, yaitu kelas VIII 6, ditetapkan sebagai kelas eksperimen yang pembelajarannya menggunakan model pembelajaran Auditory Intellectually Repetition (AIR) dan yang terambil kedua yaitu kelas VIII 5, 
ditetapkan sebagai kelas kontrol yang pembelajarannya menggunakan model konvensional.

Pengujian hipotesis dilakukan secara statistic dengan menggunakan uji t. adapun rumusan hipotesis penelitian sebagai berikut.

$H_{a}$ : Kemampuan komunikasi matematika siswa dengan model pembelajaran Auditory, Intellectually, Repetiton (AIR) lebih baik dari kemampuan komunikasi matematika siswa dengan model pembelajaran konvensional.

$H_{0}$ : Kemampuan komunikasi matematika siswa dengan model pembelajaran Auditory, Intellectually, Repetiton (AIR) sama dengan kemampuan komunikasi matematika siswa dengan model pembelajaran konvensional.

\section{HASIL DAN PEMBAHASAN}

Dalam penelitian ini, pada kelas eksperimen diberikan perlakuan sebagai variabel bebasnya yaitu Penerapan Model Pembelajaran Auditory Intellectually Repetition (AIR) sedangkan pada kelas kontrol tidak diberikan perlakuan artinya pelaksanaan pembelajaran seperti biasa. Setelah dilaksanakan penelitian data yang diperoleh dianalisis variabel terikatnya, dimana variabel terikatnya adalah kemampuan komunikasi matematika siswa. Instrument yang digunakan adalah tes akhir.

Tabel 3. Hasil Perhitungan Data Kemampuan Komunikasi Matematika

\begin{tabular}{ccccccc}
\hline No & Kelas Sampel & $\mathrm{N}$ & $\begin{array}{c}\sum x \\
\text { (Total Skor) }\end{array}$ & $\begin{array}{c}\bar{x} \\
\text { (Rata-rata) }\end{array}$ & $\mathrm{S}$ & $\mathrm{S}^{2}$ \\
\hline 1 & Eksperimen & 30 & 2535 & 84,5 & 5.85 & 34.19 \\
\hline 2 & Kontrol & 30 & 2277 & 75,9 & 7.23 & 52.3 \\
\hline
\end{tabular}

Dari Tabel 3 terlihat bahwa terdapat perbedaan nilai rata-rata hasil tes kemampuan komunikasi matematika kelas eksperimen dan kelas kontrol. Rata-rata yang diperoleh kelas eksperimen adalah 84,5, rata-rata pada kelas kontrol adalah 75,9. Menunjukan rata-rata kelas eksperimen lebih tinggi daripada kelas kontrol. Sedangkan simpangan baku kelas eksperimen adalah 5.85, simpangan baku kelas kontrol 7,23. Maka, simpangan baku kelas eksperimen lebih kecil daripada kelas kontrol, artinya semakin kecil simpangan baku maka data tidak menyebar dan menunjukan data semakin baik. Disimpulkan bahwa hasil tes kemampuan komunikasi matematika kelas eksperimen lebih baik dari hasil tes kemampuan komunikasi matematika kelas kontrol.

Perbedaan kemampuan komunikasi matematika siswa dapat dilihat melalui hasil analisa rata-rata tes setiap indikator kemampuan komunikasi siswa antara kelas eksperimen dan kelas kontrol, pada gambar 1 berikut. 


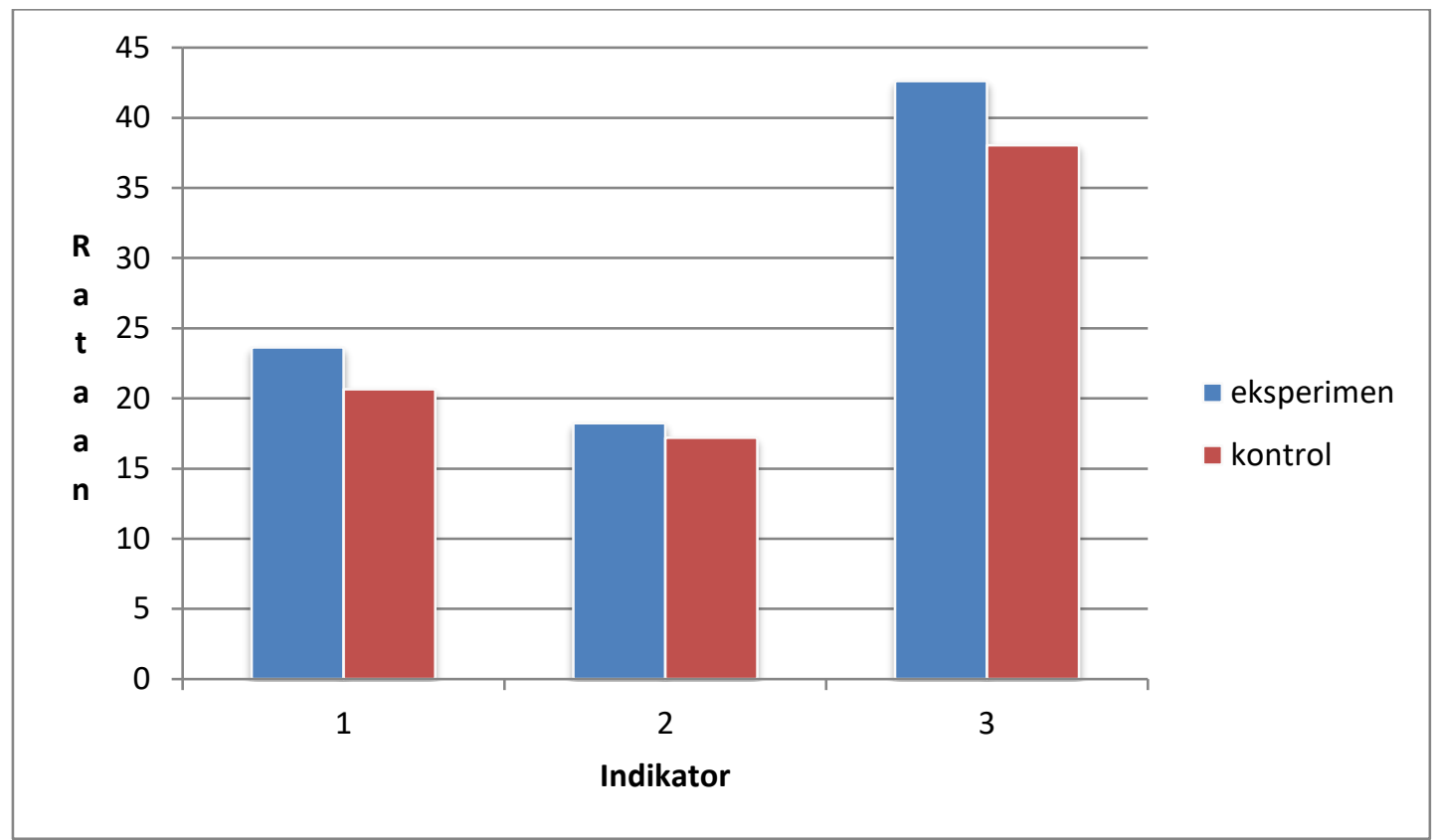

Gambar 1. Rata-rata Tes Setiap Indikator Kemampuan Komunikasi Matematika Siswa

Keterangan:

1. Menyatakan ide matematika dengan berbicara, menulis, demonstrasi, dan menggambarkannya dalam bentuk visual.

2. Memahami, menginterpretasi, dan menilai ide matematika yang disajikan dalam tulisan, lisan atau bentuk visual

3. Menggunakan kosa kata/bahasa, notasi dan struktur tematik untuk menyatakan ide, menggambarkan hubungan, dan pembuatan model

Dari gambar 1 di atas terlihat bahwa pada indikator 1 sampai indikator 3 kelas eksperimen memiliki frekuensi lebih tinggi dibandingkan dengan kelas kontrol. Ratarata tertinggi dicapai oleh indikator 3, yaitu Menggunakan kosa kata/bahasa, notasi dan struktur tematik untuk menyatakan ide, menggambarkan hubungan, dan pembuatan model. Dari perbandingan frekuensi tersebut maka dapat disimpulkan bahwa indikator kemampuan komunikasi matematika siswa pada kelas eksperimen lebih baik dari pada kelas control.

Untuk menarik kesimpulan dari hasil penelitian yang dilakukan, maka data yang diperoleh dari tes kemampuan komunikasi matematika siswa dilakukan analisis data secara statistik yaitu uji hipotesis dengan Uji Independent Samples T-Test atau uji t. Sebelum dilakukan uji $\mathrm{t}$ terlebih dahulu penulis melakukan uji normalitas dan homogenitas.

\section{Uji Normalitas}

Uji normalitas dilakukan dengan menggunakan software SPSS 22. Uji ini dilakukan bertujuan untuk melihat apakah sampel berdistribusi normal atau tidak. Uji ini dilakukan kepada kedua kelas sampel yaitu kelas eksperimen dan kelas kontrol. Hasil perhitungan uji normalitas kedua sampel dapat dilihat pada Tabel 4 berikut. 
Tabel 4. Hasil Perhitungan Uji Normalitas Kelas Sampel

\begin{tabular}{|c|c|c|}
\hline Sampel & Nilai Sig. & Keterangan \\
\hline Eksperimen & .067 & Normal \\
\hline Kontrol & $.200^{*}$ & Normal \\
\hline
\end{tabular}

Dari Tabel 4 terlihat bahwa nilai signifikan pada kelas eksperimen adalah 0,067 dan nilai signifikan pada kelas kontrol adalah 0,200. Karena signifikan pada kedua kelas sampel lebih besar dari $\alpha=0,05$ maka dapat disimpulkan bahwa kedua kelas sampel berdistribusi normal.

\section{Uji Homogenitas}

Uji homogenitas dianalisis dengan menggunakan software SPSS 22. Uji homogenitas bertujuan untuk melihat apakah kedua sampel mempunyai variansi yang homogen atau tidak. Nilai signifikan yang diperoleh adalah 0.389 dan $\alpha=0,05$. Karena signifikan $\geq \alpha$ maka dapat disimpulkan bahwa kedua kelas sampel memiliki variansi yang homongenitas.

\section{Uji Hipotesis}

Setelah sampel berdistribusi normal dan memiliki variansi yang homogen maka dilanjutkan dengan uji hipotesis dengan cara menggunakan Uji-t. Berdasarkan uji t Nilai $t_{\text {hitung }}>\mathrm{t}_{\text {tabel }}(5.065>-2.002)$ dengan (df) $\mathrm{n}-2$ maka $\mathrm{H}_{0}$ ditolak. Jadi dapat disimpulkan bahwa "kemampuan komunikasi matematika siswa dengan menggunakan model pembelajaran Auditory Intellectually Repetition (AIR) lebih baik dari pada kemampuan komunikasi matematika siswa dengan model pembelajaran konvensional".

\section{KESIMPULAN}

Berdasarkan hasil penelitian yang dilakukan pada tahun pelajaran 2016/2017 yaitu kemampuan komunikasi matematika siswa menggunakan model pembelajaran Auditory Intellectually Repetition (AIR) lebih baik daripada kemampuan komunikasi matematika siswa menggunakan pembelajaran konvensional kelas VIII SMP Negeri 1 Pasir Penyu.

\section{DAFTAR PUSTAKA}

Ansari, I. B. 2016. Komunikasi Matematik. Banda Aceh: Penerbit PeNA.

Darmadi, H. 2013. Metode Penelitian Pendidikan dan Sosial. Bandung: Alfabeta.

Hamzah, A. 2014. Perencanaan dan Strategi Pembelajaran Matematika. Jakarta: PT. Raja Grafindo Persada.

Hariani, S. M. 2016. Upaya Meningkatkan Kreativitas dan hasil belajar matematika siswa dengan menggunakan Model AIR (Auditory, Intellectually, Repetition) pada Siswa Kelas VII MTs Negeri Rantauprapat T.P2014/2015. Jurnal Edu Tech. Vol.2 No.1 Maret 2016.

Priyatno, D. 2014. SPSS 22 Pengolahan data terpraktis. Yogyakarta: penerbit ANDI. Sohimin, A. 2002. 68 Model Pembelajaran Inovatif dalam Kurikulum 2013. Bandung: Penerbit Nuansa. 